OPEN ACCESS

Edited by:

Shohei Hori,

The University of Tokyo, Japan

Reviewed by: Shunsuke Chikuma, Keio University, Japan

David Michael Sansom, University College London, United Kingdom

${ }^{*}$ Correspondence: William K. Decker decker@bcm.edu

Specialty section: This article was submitted to Immunological Tolerance and Regulation,

a section of the journal

Frontiers in Immunology

Received: 18 September 2020 Accepted: 05 November 2020 Published: 15 December 2020

Citation:

Oyewole-Said D, Konduri V

Vazquez-Perez J, Weldon SA, Levitt JM and Decker WK (2020) Beyond T-Cells: Functional Characterization of CTLA-4 Expression in Immune and Non-Immune Cell Types.

Front. Immunol. 11:608024. doi: 10.3389/fimmu.2020.608024

\section{Beyond T-Cells: Functional Characterization of CTLA-4 Expression in Immune and Non-Immune Cell Types}

Damilola Oyewole-Said ${ }^{1}$, Vanaja Konduri ${ }^{1}$, Jonathan Vazquez-Perez ${ }^{1}$, Scott A. Weldon ${ }^{2}$, Jonathan M. Levitt ${ }^{1,3,4}$ and William K. Decker ${ }^{1,3,5 *}$

1 Department of Pathology \& Immunology, Baylor College of Medicine, Houston, TX, United States, 2 Michael E. DeBakey Department of Surgery, Baylor College of Medicine, Houston, TX, United States, ${ }^{3}$ Dan L. Duncan Cancer Center, Baylor College of Medicine, Houston, TX, United States, ${ }^{4}$ Scott Department of Urology, Baylor College of Medicine, Houston, TX, United States, ${ }^{5}$ Center for Cell and Gene Therapy, Baylor College of Medicine, Houston, TX, United States

The immune response consists of a finely-tuned program, the activation of which must be coupled with inhibitory mechanisms whenever initiated. This ensures tight control of beneficial anti-pathogen and anti-tumor responses while preserving tissue integrity, promoting tissue repair, and safeguarding against autoimmunity. A cogent example of this binary response is in the mobilization of co-stimulatory and co-inhibitory signaling in regulating the strength and type of a T-cell response. Of particular importance is the costimulatory molecule CD28 which is countered by CTLA-4. While the role of CD28 in the immune response has been thoroughly elucidated, many aspects of CTLA-4 biology remain controversial. The expression of CD28 is largely constrained to constitutive expression in T-cells and as such, teasing out its function has been somewhat simplified by a limited and specific expression profile. The expression of CTLA-4, on the other hand, while reported predominantly in T-cells, has also been described on a diverse repertoire of cells within both lymphoid and myeloid lineages as well as on the surface of tumors. Nonetheless, the function of CTLA-4 has been mostly described within the context of T-cell biology. The focus on T-cell biology may be a direct result of the high degree of amino acid sequence homology and the co-expression pattern of CD28 and CTLA-4, which initially led to the discovery of CTLA-4 as a counter receptor to CD28 (for which a T-cell-activating role had already been described). Furthermore, observations of the outsized role of CTLA-4 in $T_{\text {reg-mediated immune suppression and the striking }}$ phenotype of T-cell hyperproliferation and resultant disease in CTLA-4 ${ }^{-/}$mice contribute to an appropriate T-cell-centric focus in the study of CTLA-4. Complete elucidation of CTLA-4 biology, however, may require a more nuanced understanding of its role in a context other than that of T-cells. This makes particular sense in light of the remarkable, yet limited utility of anti-CTLA- 4 antibodies in the treatment of cancers and of CTLA-4-Ig in autoimmune disorders like rheumatoid arthritis. By fully deducing the biology 


\section{of CTLA-4-regulated immune homeostasis, bottlenecks that hinder the widespread applicability of CTLA-4-based immunotherapies can be resolved.}

Keywords: CTLA-4, peripheral tolerance, immune regulation, tumor immunity, CD28

\section{INTRODUCTION}

CD28 and CTLA-4 are homologous glycoproteins of the immunoglobulin superfamily (1). Despite their shared ability to bind CD80/B7.1 and CD86/B7.2 (B7 proteins) $(2,3)$, these molecules mediate opposing effects on T-cell function. While CD28 promotes T-cell activation and proliferation $(4,5)$, CTLA-4 is reported to dampen T-cell responses through a variety of mechanisms (6-12). Prior to activation, conventional T-cells $\left(\mathrm{T}_{\text {conv }}\right)$ express low levels of CTLA-4, predominantly in intracellular compartments. Upon activation, CTLA-4 expression is upregulated and becomes increasingly detectable on the cell surface, peaking around $36 \mathrm{~h}$ post-activation (13-15). In Tregs on the other hand, transmembrane CTLA-4 is constitutively expressed and plays an integral role in Treg homeostasis and function (16-18). In general, T-cell CTLA-4 is largely constrained to intracellular expression although some surface expression may be detectable owing to the rapid, continuous shuttling of CTLA-4 between intracellular compartments and the plasma membrane (10, 19-22).

Intracellular trafficking of CTLA-4 requires the recruitment of a specific repertoire of proteins by vesicle-bound-intracellular CTLA4 and by CTLA- 4 at the plasma membrane $(9,23)$. These proteinprotein interactions are largely mediated by the recruitment of the clathrin adaptor complexes AP-1 (at the trans-golgi) and AP-2 (at the plasma membrane) by the intracellular YVKM motif of CTLA-4 (10, 19, 20, 24, 25). Tight control of turnover is another important regulator of CTLA-4 expression and function. Specifically, lipopolysaccharide-responsive and beige-like anchor protein (LRBA) protects CTLA-4 from lysosomal degradation thus promoting its accumulation in the cytoplasm and subsequent surface expression (26). Although LRBA deficiency presents with a variable phenotype $(26,27)$, autoimmunity and hypogammaglobulinemia characterized by decreased Treg, total Bcell, class-switched B-cell and plasmablast frequency along with an increased proportion of circulating $\mathrm{T}_{\mathrm{fh}}$ are prevalent (27-30). In these patients, CTLA-4-mediated functions can be substantially impaired (26-31).

The most widely reported mechanism of CTLA-4-mediated inhibition is its competitive binding of $\mathrm{B} 7$ proteins to which it has a $10-100$-fold greater affinity than $\operatorname{CD} 28(32,33)$. As a result, T-cells are deprived of $\mathrm{CD} 28$-mediated activating signals. Subsequent to binding B7 proteins, CTLA-4 has also been described to further deprive T-cells of stimulatory signaling via transendocytosis of B7 molecules from the surface of APCs (11, 22), inhibition of proximal T-cell receptor (TCR) signaling (6), and disruption of the c-SMAC (central supramolecular cluster) within the immunological synapse (34). The disruption of CD28 signaling is generally accepted as the major pathway through which CTLA-4 functions as evidenced by observations that fatal lymphoproliferation observed in CTLA- $4^{-/-}$mice is rescued by the genetic deletion of CD28 (35).

Aside from these cell-extrinsic mechanisms, CTLA-4 has also been shown to function through cell-intrinsic mechanisms. Upon binding of B7 molecules, CTLA-4 has been reported to signal through PI3K and PKC $\delta$ in activated conventional T-cells $(23,36$, 37). In these cells, CTLA-4 signaling reinforces its previously described inhibitory role by recruiting the phosphatases SHP-2 and PP2A to the immunological synapse, thereby reversing the phosphorylation of secondary messengers by TCR co-receptors and co-stimulatory molecules (38-41). This cell-intrinsic program also serves to limit the contact-dependent suppressive capacity of Tregs through PKC- $\eta$ signaling (7) and prevent activationinduced cell death, particularly in $\mathrm{T}_{\mathrm{H}} 2$ cells, by promoting $\mathrm{Bcl} 2$ expression while downregulating FasL (42). In addition, CTLA-4 ligation enforces a reversal of the TCR stop signal which may decrease the contact time between T-cells and APCs and could also explain the apparent ability of CTLA- 4 to drive $\mathrm{T}_{\mathrm{H}}$ cell migration to secondary lymphoid organs $(37,43)$.

\section{B-CELLS}

While the T-cell phenotype in CTLA- $4^{-1-}$ mice is striking and largely accounts for the observed tissue destruction, B-cells in these mice also displayed a hyperactivated phenotype. This distinctive B-cell signature includes hypergammaglobulinemia as well as upregulated expression of CD86, FAS and CD5 on Bcells (44). Accordingly, CTLA-4 expression in B-cells was subsequently demonstated $(31,45-48)$. Coupled with reports of auto-antibody production and deficiencies in antigen-specific antibody generation in LRBA-deficient patients (29), these observations provided the rationale for studying CTLA-4 in the context of B-cell activation. Initial reports indicated that the role of CTLA-4 in limiting B-cell responses was mediated via $\mathrm{T}_{\text {fh, }}, \mathrm{T}_{\text {freg, }}$, and $\mathrm{T}_{\text {reg }}$ expression of CTLA-4 (49). The authors reported that CTLA-4-mediated control of B-cell activation could occur within or outside of the germinal center and could occur independently of CD80 and CD86. The experiments outlined in this report demonstrated, for the first time, that CTLA-4 could extrinsically subvert B-cell activation. The observations, however, did not preclude cell-intrinsic mechanisms of CTLA-4-mediated constraint of B-cell responses.

Aside from the expression of CTLA-4 on human B-cell chronic lymphocytic leukemia (discussed in 'Tumors' section), the expression of CTLA-4 on B1 and B2 B-cells has been sparsely studied but well-validated in mice and humans. The stimuli which drive B2 B-cell expression of CTLA-4 remain controversial, however. Some reports assert that B2 B-cell CTLA-4 expression may be driven by PMA, LPS + IL-4, or CD40 + IL-4 stimulation 
(45-47), while others determined that B2 B-cell CTLA-4 expression was strictly thymus-dependent $(48,50)$ and could not be driven by Protein Kinase $\mathrm{C}$ activation, cytokine stimulation, or bacterial products alone. Further studies have so far failed to fully resolve the impact of these different stimuli on Bcell CTLA-4 expression. Within the B-cell compartment, it is important to determine the physiology of CTLA-4 expression in both B1 and B2 B-cells, each of which undertakes distinct roles within the broader immune response. In particular, B1 B-cells participate in innate immune responses by constitutively generating low affinity, highly cross-reactive antibodies (referred to as natural antibodies) in a T-cell-independent manner. These cells are self-renewing and primarily localized to pleural and peritoneal tissues. Consequently, B1 B-cells and their antibodies are the brokers of innate humoral responses. B2 B-cells, on the other hand, are commonly taken to be the conventional B-cell subset. They participate in the adaptive immune response, generating highly specific antibodies in a T-cell-dependent or independent manner during the later phase of an immune response. In contrast to $\mathrm{B} 1 \mathrm{~B}$-cells, these cells are generally located in the bone marrow and secondary lymphoid organs. Additionally, B2 B-cells may be recruited to peripheral organs during an immune response. In B2 B-cells, surface CTLA-4 expression was reported to be fivefold lower than observed in activated T-cells and was transient, peaking within $48 \mathrm{~h}$ and disappearing by $96 \mathrm{~h}$ after stimulation (48). Importantly, the transfer of CTLA-4 from T-cells to co-cultured B2 B-cells was ruled out by virtue of the observation that CTLA- $4^{-/-}$B2-cells remain negative upon co-culture with CTLA-4-sufficient T-cells. Although B2 B-cell CTLA-4 was not required for B-cell differentiation or homeostasis in mice (48), it was reported to restrain isotype switching. Particularly, CTLA-4 ligation limited the production of antigen-specific and total IgM, IgG and IgE (46, 48) but not of natural antibodies (48). CTLA-4 ligation by human B2 B-cells led to the downregulation of surface and secreted IgG as well as IL-8, TNF $\alpha$ and IL-10 (45). In contrast, the role of CTLA-4 in B1 B-cell development and function remains undefined, although its expression has been reported (51). Given the reported lack of alterations to natural antibody production in CTLA- $4^{-/-}$mice, it is possible that B1 CTLA-4 exerts a cellextrinsic inhibitory function on the immune response.

Whether B-cell CTLA-4, in fact, possesses cell-extrinsic functions remains to be determined. As previously stated, LRBA-deficient patients and mice (with limited surface CTLA4 expression) present with diminished total B-cell, IgG classswitched B-cell and plasmablast numbers, accompanied by increased frequency of circulating $\mathrm{T}_{\mathrm{fh}}$ and the generation of autoantibodies, despite reported hypogammaglobulinemia (26, $27,29,52)$. While the administration of CTLA-4-Ig alleviates the overall clinical phenotype and reduces $\mathrm{T}_{\mathrm{fh}}$ dysfunction in LRBAdeficient patients (26), it is unclear whether the observed therapeutic effects may be solely attributed to restored Tfh control of B-cell activation or by the impact of CTLA-4-Ig directly on B-cells. As such, it remains to be determined whether B-cell CTLA-4 possesses cell-intrinsic functions. Given the co-expression of CTLA-4 and B7 on B-cells, it may be valuable to clarify all pertinent functions of these molecules in the context of B-cell biology since they pertain to both B-cell:Bcell interactions as well as B-cell:T-cell interactions within secondary lymphoid organs. It also remains unclear whether specific B-cell subsets such as marginal zone B-cells and memory B-cells possess distinct CTLA-4-mediated functions during an ongoing primary or recall immune response. These questions might be resolved through further studies utilizing B-cell-specific deletions of CTLA-4 coupled with CTLA-4-Ig models of rescue as well as studies of bone marrow chimeric mice. Additionally, the specific mechanisms which drive B-cell CTLA-4 expression and function are yet to be fully understood beyond their T-cell dependence. Specifically, the B-cell:T-cell interactions and resultant signaling cascades that drive CTLA-4 expression in B-cells are unknown. Furthermore, the mechanisms through which B-cell CTLA-4 restrains antigen-specific IgM and IgE production have not been determined, although STAT6 and $\mathrm{NF} \kappa \mathrm{B}$ activation were shown to be suppressed upon B-cell CTLA-4 ligation. Furthermore, the expression and function of CTLA-4 on non-malignant human B-cells has not been investigated. These mechanisms could prove important for elucidating pathways involved in the generation of allergic and autoinflammatory diseases, particularly those with confirmed Bcell involvement.

\section{NK CELLS}

Accounts of CTLA-4 expression in NK cells are even more scarce than those in B-cells. Presently, our knowledge is based primarily on one mouse and one human study. Interestingly, although both studies are in agreement regarding the conditions which drive the expression of CTLA-4 in their respective model systems, they come to disparate conclusions regarding its function in NK cells. In mouse studies conducted by the Cerwenka group (53), only IL-2-primed NK cells and tumorinfiltrating NK cells were observed to express CTLA-4. Similar to T-cells, CTLA-4 expression in NK cells was largely constrained to intracellular compartments. Moreover, CTLA-4 levels in IL-2primed mouse NK cells could be modulated by cytokine treatment in their in vitro culture system. In particular, the combination of IL-12 and IL-18 but not IL-15 synergized with IL-2 to further enhance CTLA- 4 expression while TGF- $\beta$ served to counteract CTLA-4 expression. These observations were recapitulated in human studies carried out by Lougaris et al (54). Similarly, IL-2-primed human NK cells expressed intracellular CTLA-4, which could be further increased by IL12 + IL-18 treatment. Presumably, the impact of IL-12 and IL-18 on the expression of NK CTLA-4 is of physiological relevance, since these cytokines have already been described as important modulators of NK cell phenotype, especially in the context of NK-DC crosstalk. Specifically, DCs (and macrophages) secrete IL-12 and IL-18 which synergize to boost NK cell-mediated cytotoxicity, IFN $-\gamma$ production, and IL2R $\alpha$ expression $(55,56)$. Regarding the function of NK CTLA-4, there is a disagreement between the mouse and human data. CTLA-4 ligation was shown 
to be inhibitory to mouse NK cell function (53) while, conversely, the absence of such ligation in human NK cells resulted in limited function (54). Specifically, in mouse NK cells, CTLA-4 was shown to limit the expression of IFN- $\gamma$ upon B7 ligation or co-culture with mature dendritic cells.

When mature DCs were pre-treated with CTLA-4-Ig before co-culture with NK cells, IFN- $\gamma$ expression by NK cells was partly inhibited. This experiment indicated that CTLA-4 may mediate its inhibitory role partly through B7 blockade in mice (53). However, the role of CTLA-4 in NK cell cytotoxicity was not examined in this study. Although CTLA-4-regulated IFN- $\gamma$ likely plays a salient role in NK-mediated immunity, understanding the role of CTLA-4 in NK-mediated cytotoxicity could be an equally important phenomenon that remains unexamined.

In human NK cells, CTLA-4 function was examined in the contexts of $\mathrm{NK}$ cell development, IFN- $\gamma$ production, and cytotoxicity (54). Here, CTLA-4 haploinsufficiency was not observed to affect NK cell development; rather, it was shown to limit IFN- $\gamma$ expression in response to cytokine stimulation as well as degranulation in response to target K562 cells. This was surprising given the inhibitory role already described for mouse NK CTLA-4 and both mouse and human T-cell CTLA-4. In light of the disagreement between human and mouse NK cell studies as well as the variable expression of CD28 $(57,58)$ on human NK cells [unlike mouse NK cells (53)], the role of NK cell CTLA-4 in the immune response of each organism must be thoroughly validated. It will be important to determine the function of $\mathrm{NK}$ CTLA-4 particularly at the early phase of an immune response, the time at which NK cells are most often activated.

\section{MONOCYTES AND DENDRITIC CELLS}

The interaction between dendritic cells (DCs) and T-cells is critical to determining the type, strength, and likely the duration of T-cell-dependent immune responses. Not only do dendritic cells prime de novo $\mathrm{T}$-cell activation, they also contribute to the dampening of $\mathrm{T}$-cell responses through negative selection in the thymus and can induce tolerance or anergy in the periphery (5961). While the expression of CTLA-4 has been reported for T-cells and DCs, investigations into the origins and function of T-cell CTLA-4 are far more numerous than similar explorations of DC CTLA-4. In addition to the regulation of T-cell responses, the interaction between DCs and NK cells as well as nonimmune cells is important to regulating the overall immune response. While it has been demonstrated that ligation of CTLA4 molecules on the surface of DCs can engender a tolerogenic DC phenotype involving IL-10 and IDO expression $(62,63)$, the direct impact of DC CTLA-4 on immune cell phenotype is unknown. Initial reports demonstrated that freshly isolated $\mathrm{CD} 14^{+}$human monocytes could express CTLA-4 (64). Like Tcell CTLA-4, this was largely restricted to intracellular compartments and could be upregulated by activation of Protein Kinase $\mathrm{C}$ (PKC) via treatment of monocytes with PMA and IFN- $\gamma$ (64). These early observations made no conclusions as to whether these activated monocytes were differentiated into dendritic cells or macrophages, both of which could be derived from cultured monocytes. More recent investigations, however, determined that bone marrow monocyte-derived dendritic cells were capable of upregulating soluble and transmembrane isoforms of CTLA-4 upon maturation with LPS, Poly I:C or a cocktail of inflammatory cytokines $(63,65)$. Notably, Immature DCs expressed little to no intracellular or surface CTLA-4. The expression of CTLA-4 in DCs was also determined to delineate a novel subset of regulatory DCs present in hepatocellular carcinoma patients. In these patients, CD $14^{+}$CTLA $-4^{+}$DCs also expressed the inhibitory molecules PD-1, IDO and IL-10 (62). Cross-linking of CTLA-4 in these DCs further enhanced the expression of IDO and IL-10, which presumably contributed to immunosuppression and subsequent tumor escape.

Due to the lack of homogeneity within the DC compartment, it became necessary to define which DC subsets expressed CTLA-4. It was determined that while both $\mathrm{CD}_{1}{ }^{+}$and $\mathrm{CD} 1 \mathrm{a}^{-}$ dendritic cells expressed intracellular CTLA-4 upon maturation, only CD1a ${ }^{+}$DCs expressed measurable levels of surface CTLA-4 (66). Further functional characterization of DC CTLA-4 followed, leading to the determination that ligation of the molecule inhibited AP-1 and NFkB activity and suppressed DC maturation and proliferation (64). Such ligation also promoted the expression of IL-10 and suppressed IL- 8 release and T-cell responses in vitro. Accordingly, CTLA-4 ligation did not significantly impact antigen presentation, since the molecule was minimally expressed on immature dendritic cells (64). Further studies by Halpert et al. demonstrated for the first time that CTLA-4 expressed by both human and mouse bone marrow or monocyte-derived DC was capable of exerting cellextrinsic effects on neighboring dendritic cells. This work determined that CTLA-4 was packaged into extracellular vesicles (EVs) which could be taken up by neighboring dendritic cells. Upon uptake of these CTLA $-4^{+}$EVs, B7 expression on the surface of recipient dendritic cells was significantly downregulated (Figure 1). Furthermore, the expression of CTLA-4 by a dendritic cell vaccine was found to impact antitumor efficacy (65). siRNA-mediated knockdown of CTLA-4 in a DC vaccine significantly improved tumor control and survival, correlating with vastly increased frequency of activated $\mathrm{CD}^{+} \mathrm{T}$-cells. This result was verified in human monocyte-derived DC which, following treatment with CTLA4 siRNA, stimulated the proliferation of far greater numbers of IFN- $\gamma^{+} \mathrm{CD}^{+}$T-cells and far fewer $\mathrm{CD}^{+} \mathrm{CD}^{+} 5^{+}$Foxp $3^{+}$ phenotypic $\mathrm{T}_{\text {regs. }}$ Accordingly, the same authors subsequently demonstrated that secretion of microvesicular CTLA-4 by dendritic cells plays a critical role in the regulation of $\mathrm{T}_{\mathrm{H}}$ polarization and promulgation of $\mathrm{T}_{\mathrm{H}} 1$ immunity (67). Although some features of DC CTLA-4 physiology have been determined, several important aspects are yet to be resolved. For instance, the role of CTLA-4 on the development of DCs and on DC-mediated negative selection of T-cells is unknown. Likewise, the underlying mechanisms which drive the effects of DC CTLA4 and CTLA $-4^{+}$EVs on other dendritic cells, T-cells and antitumor immunity are unknown. While the expression of DC 


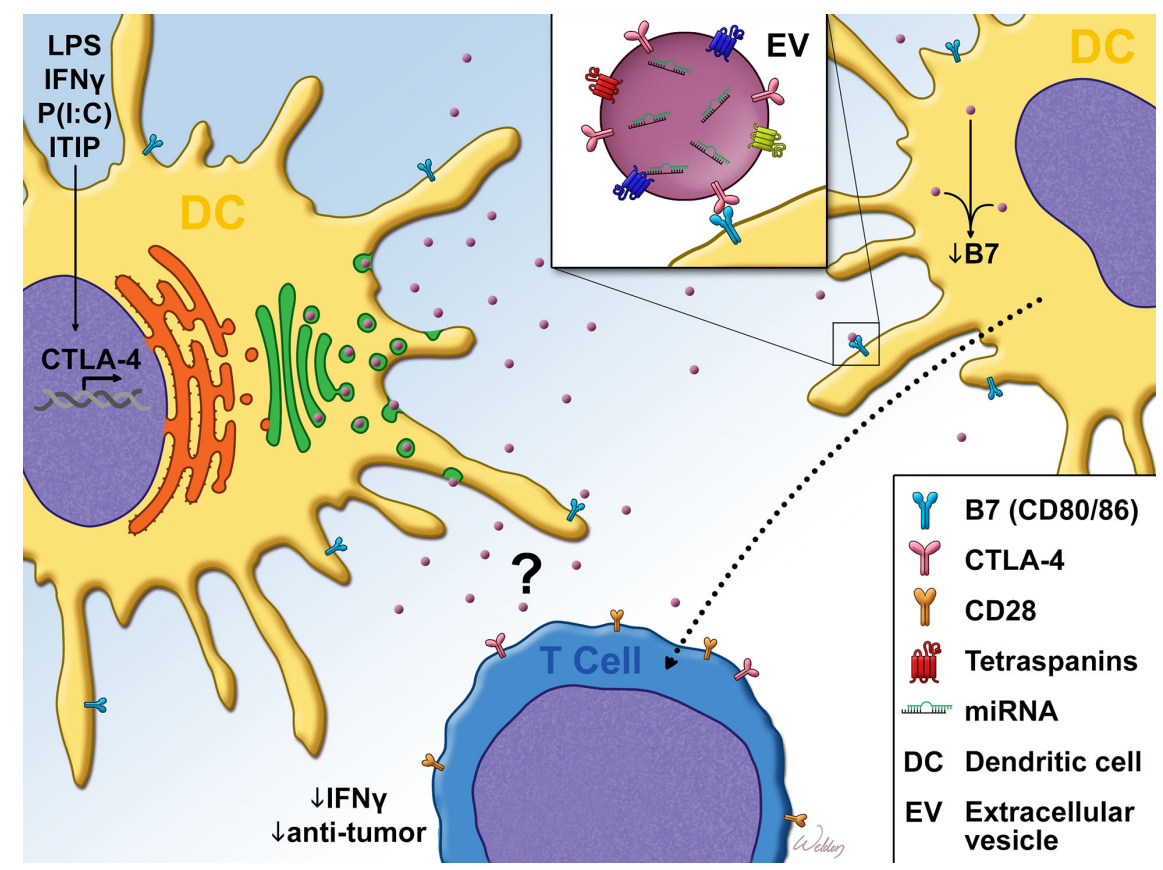

FIGURE 1 | Dendritic cell CTLA-4 suppresses T-cell responses Cytokine or TLR agonist stimulation promotes dendritic cell (DC). maturation as well as the expression of CTLA-4. Unlike T-cell CTLA-4 which is predominantly localized to the plasma membrane, DC CTLA-4 expression is diffuse, with some localization to the trans-golgi. After leaving the golgi, DC CTLA-4 is packaged into CD63 ${ }^{+}$Rab5 ${ }^{+}$extracellular vesicles (EVs), which are then exported from the cell. Once in the extracellular space, bystander DC take up the EVs in a B7 (CD80/CD86)-dependent manner. Uptake of EVs in this fashion resulted in the downregulation of surface

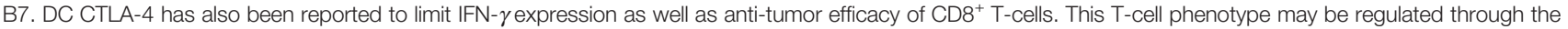
direct impact of the CTLA4 ${ }^{+}$EVs on T-cells or through bystander DC that take up CTLA4 ${ }^{+}$EVs, as evidenced by DC-T cell co-culture experiments and in vivo DC vaccine studies. LPS, Lipopolysaccharide; IFN- $\gamma$, Interferon-gamma; P(I:C), Polyinosinic:polycytidylic acid; ITIP, pro-inflammatory cytokine cocktail which consists of: IL-1 $\beta$, INF $\alpha$, IL-6 and Prostaglandin $\mathrm{E}_{2}$.

CTLA-4 in bone marrow-derived DCs has been thoroughly validated, it is unclear which in vivo DC subsets express CTLA-4 in a similar fashion. Our unpublished observations from mouse splenic DCs have revealed that the expression of CTLA- 4 by DC subsets is indeed differential. We observed that cDC1 cells (conventional DC type 1) expressed significantly greater intracellular CTLA-4 levels than cDC2 cells, monocytes, monocyte-derived DCs and plasmacytoid DCs (pDCs). While monocytes expressed undetectable levels of intracellular CTLA-4, the remaining subsets expressed comparable levels of CTLA-4. This would mark the first report of CTLA-4 expression in $\mathrm{CDC} 1, \mathrm{cDC} 2$ and pDC subsets. Our report, in contrast to others (62-66), differs with regard to the distinct absence of CTLA-4 expression in monocytes. This disparity likely stems from our stringent gating of mouse DC subsets [as previously described (68)], which differs from the CD14-predicated gating of monocytes in previous reports. These observations, coupled with reports of CTLA-4 expression in MDSCs and M2 macrophages in HNSCC tumors (69), underscore the importance of investigating the physiology of CTLA-4 within the monocyte lineage, particularly its utility in type I and type II T-cell responses as well as in T-cellindependent responses.

\section{TUMORS}

The earliest report of CTLA-4 expression in tumors came from observations made in leukemias as well as Hodgkin's and nonHodgkin's lymphomas (NHL) (70). CTLA-4 was detected on acute and chronic myeloid leukemias, large granular lymphocytic leukemia and malignant follicular B-cells of patients with lowgrade B-cell lymphoma as well as non-malignant reactive B-cells in NHL patients. While CTLA-4 was detected in both B-cell chronic and acute lymphocytic leukemia, it was reported only in T-cell acute and not chronic lymphocytic leukemia $(47,70)$. CTLA-4 expression has also been reported in the lymphoblastic Raji and Daudi cell lines (71).

In patients with Hodgkin's disease, CTLA-4 was not detected on any neoplastic lymphocytes and was notably absent in ReedSternberg cells (70). Although CTLA-4 is known as a negative regulator of T-cell proliferation, CTLA-4 expression was paradoxically detected on the malignant $\mathrm{T}$-cells of patients with peripheral but not lymphoblastic or anaplastic NonHodgkin lymphomas (NHL) (70). While this expression of CTLA-4 on neoplastic peripheral T-cells would be in keeping with the inducible expression of CTLA-4 on activated T-cells, it calls into question the mechanisms that underlie the seeming loss 
of intrinsic CTLA-4-mediated control of T-cell proliferation (72, 73) as well as the activating signals which drive CTLA-4 expression in neoplasms. Perhaps CTLA-4 expression promotes tumor escape in the periphery (by inhibiting antitumor responses) but is incapable of inhibiting malignant lymphocyte proliferation through well-documented cellintrinsic modes of immune suppression. Although these questions are yet to be resolved, observations derived from studies of B-cell CTLA-4 in CLL have revealed important clues that could mirror the physiology of CTLA-4 in T-cell malignancies $(74,75)$. It was observed that B-cell CTLA-4 was most highly expressed in the bone marrow and peripheral blood in comparison to lymph node B-cells where expression was significantly lower (76). In these malignant B-cells, CTLA-4 expression was constitutive and intracellular but could be driven to the surface via co-culture with activated T-cells. Here, neoplastic B-cell CTLA-4 successfully mediated transendocytosis of surface CD80 (from CD80-GFP ${ }^{+}$cells) and downregulated IL-2 production by co-cultured T-cells (75). Functional characterization of tumor CTLA-4 function proceeded with the study of cell-intrinsic effects of CTLA-4 on B-cells in CLL. Here, decreased expression of CTLA-4 correlated with increased expression of c-Myc, phospho-STAT1, NFATc2, phospho-c-Fos, and $\mathrm{Bcl} 2$, molecules which presumably are downstream of B-cell Receptor (BCR) activation (76). Accordingly, CTLA-4 downregulation also correlated with decreased apoptosis in CLL B-cells. These lines of evidence suggest that neoplastic B-cell CTLA-4 is functionally suppressive through both cell-intrinsic and cell-extrinsic pathways. It would seem that malignant B-cell CTLA-4, at least, is capable of dampening T-cell-mediated anti-tumor immune responses while paradoxically limiting B-cell proliferation and survival. Perhaps there remains sufficient heterogeneity, with regard to CTLA-4 expression, such that lymphoproliferation can occur with CTLA4 $4^{-}$malignant B-cells in the lymph node with concurrent inhibition of anti-tumor responses by CTLA $-4^{+}$malignant B-cells in peripheral blood or bone marrow, thus favoring overall tumor progression.

The prognostic value of B-cell CTLA-4 in CLL is not yet clearcut. Some reports suggest that CTLA-4 expression promotes the survival of leukemic B-cells and correlates with disease progression $(74,76)$, while others assert that CTLA-4 expression may be a marker of improved outcomes (77). This prognostic mirrors the disparate conclusions that have been drawn regarding the expression of CTLA-4 in non-immune cell malignancies. In some breast cancers $(78,79)$, thyomomas (80), esophageal carcinomas (81) and nasopharyngeal carcinomas (82), tumor expression of CTLA-4 correlated with poor prognosis while no relationship to survival was observed with testicular germ cell tumors (83). Although the basis for the negative correlation of CTLA-4 expression to prognosis was not determined in the relevant studies, it is possible (perhaps even probable) that such poor prognoses were mediated by the direct suppression of immune effector cell function by CTLA $4^{+}$tumor tissue. A cogent demonstration of this immune suppression was demonstrated in breast cancer cells, which have been shown to express CTLA-4. In this study, CTLA $-4^{+}$breast cancer cells suppressed dendritic cell maturation, antigen presentation, and inflammatory cytokine expression, ultimately dampening $\mathrm{T}_{\mathrm{H}} 1$ and CTL responses (79). Yet, in non-small cell lung cancer (NSCLC) (84) and when expressed in the hepatic hilar region of extrahepatic bile duct cancer patients (85), studies determined that CTLA-4 correlated with improved survival. However, later studies showed that disease-specific survival did not correlate with primary tumor CTLA-4 expression (86). Rather, the prognostic value of CTLA-4 in NSCLC could only be revealed when patients were stratified by disease subtype. Here, metastatic lymph node expression of CTLA-4 correlated with poor prognosis while soluble CTLA-4 expression predicted improved prognosis in squamous cell carcinoma. CTLA-4 is reported to be highly expressed in most human and mouse melanoma cell lines as well as normal melanocytes, many primary melanomas, and melanoma stem cells with conflicting data suggesting both immune and non-immune-related roles in tumorigenesis (87-89). Altogether, the disparate effects of tumor CTLA-4 expression make a strong case for studying the effects of CTLA-4 expression within each separate microenvironment in each cancer type and at different stages of cancer progression, rather than extrapolating results from one cancer type.

\section{NON-HEMATOPOIETIC/NON-CANCER}

The study of CTLA-4 expression and function has so far been centered on hematopoietic lineages and anti-tumor responses. While the immunological role of CTLA-4 is indisputable, it is clear that the function of CTLA-4, particularly in the maintenance of tissue homeostasis and tolerization at immune-privileged sites, may be more nuanced than has been described. Moreover, immunological roles such as the ability to secrete cytokines and antimicrobial peptides in response to immune stimuli have been observed in non-hematopoietic cells (90-94). Non-hematopoietic cells have also been reported to engage hematopoietic cells, direct their differentiation, and drive autoimmune disease development (91, 93-95). Importantly, CTLA-4 polymorphisms have been linked to autoimmune conditions including type I diabetes (96, 97), Hashimoto's thyroiditis $(97,98)$, systemic lupus erythematous $(99,100)$ and celiac disease $(101)$, indicating possible roles for nonhematopoietic tissue CTLA-4 in the ontogeny and progression of autoimmune disease. As such, investigations into the expression pattern and function of CTLA-4 in non-tumor and nonhematopoietic tissue is warranted. In this regard, CTLA-4 expression has been reported in mesenchymal stem cells and placental fibroblasts $(102,103)$ as well as the aforementioned normal melanocytes. Additionally, stimulation of cultured muscle cells with IL- $1 \alpha$ IFN- $\gamma$ or IL- $2+$ anti-CD2 8 promoted CTLA-4 expression (104).

In general, human mesenchymal stem cells (MSCs) are highly immunosuppressive and have been theorized to exert their effects through a variety of mechanisms (reviewed elsewhere) (105). While the release of HLA-G and factors such as nitric oxide and $\mathrm{PGE}_{2}$ have been identified as mechanisms of MSC-induced 
TABLE 1 | Summary of Evidence of non-T-cell CTLA-4 by Cell Type.

\begin{tabular}{|c|c|c|c|c|c|}
\hline Cell type & & Experimental Evidence & Controls & Anti-CTLA-4 clone & Reference \\
\hline \multirow[t]{2}{*}{ B-cells } & $\begin{array}{l}\text { Resting and activated human and } \\
\text { mouse B-cells }\end{array}$ & $\begin{array}{l}\text { A. Flow cytometry }(45-48,50) \\
\text { B. Immunoprecipitation + western blot (50) } \\
\text { C. RT-PCR (48) } \\
\text { D. Analysis of bone marrow- chimeric mice (48) } \\
\text { E. Functional analysis of anti-CTLA-4-mediated } \\
\text { cross-linking (46) }\end{array}$ & $\begin{array}{l}\text { CTLA-4-Ig-transfected J558L murine myeloma (47), } \\
\text { T-cells and Isotype controls }(45-48,50) .\end{array}$ & $\mathrm{BNI3}(47)$ & $(45-48,50)$ \\
\hline & B1 B-cells (mouse) & $\begin{array}{l}\text { Post-hoc analysis of publicly-available B-cell } \\
\text { microarray datasets }\end{array}$ & Not provided & Not provided & (51) \\
\hline \multirow[t]{2}{*}{ NK Cells } & IL-2-primed mouse NK cells & $\begin{array}{l}\text { A. Flow cytometry } \\
\text { B. qRT-PCR } \\
\text { C. Functional analyses using CTLA-4-FC and NK } \\
\text { cells from CTLA-4 KO mice }\end{array}$ & $\begin{array}{l}\text { Isotype control for functional analyses, isotype } \\
\text { controls for flow cytometry. }\end{array}$ & $\begin{array}{l}\text { UC10-4F10-11 and UC10- } \\
\text { 4B9 }\end{array}$ & (53) \\
\hline & IL-2-primed human NK cells & Flow cytometry & $\begin{array}{l}\text { CTLA-4 haploinsufficient patient samples, isotype } \\
\text { control. }\end{array}$ & Not provided & (54) \\
\hline \multirow[t]{3}{*}{$\begin{array}{l}\text { Monocytes and } \\
\text { DCs }\end{array}$} & CD14 ${ }^{+}$Human monocytes & $\begin{array}{l}\text { A. Flow Cytometry }(63,64) \\
\text { B. Fluorescence microscopy (64) } \\
\text { C. Western blot (64) } \\
\text { D. RT-PCR (64) }\end{array}$ & $\begin{array}{l}\text { CTLA-4-Ig-transfected J558L murine myeloma (63), } \\
\text { T-cells (64), isotype control ( } 47,63,64) \text {, C33a } \\
\text { cervical cancer cell line and surface staining of resting } \\
\text { T-cells (64). }\end{array}$ & $\begin{array}{l}\text { BNI3 (63); N-19 and AF-386- } \\
\text { PB (64) }\end{array}$ & $(47,63,64)$ \\
\hline & $\begin{array}{l}\text { Human monocyte-derived dendritic } \\
\text { cells }\end{array}$ & $\begin{array}{l}\text { A. Flow Cytometry }(63,65,66) \\
\text { B. Western blot }(65,66) \\
\text { C. Confocal microscopy }(65) \\
\text { D. siRNA knockdown }(65) \\
\text { E. Immunoprecipitation }(65) \\
\text { F. } \\
\text { 66-PCR and PCR product sequencing }(65, \\
\text { G. } \\
\text { Gunctional analyses }(63,65,66)\end{array}$ & $\begin{array}{l}\text { PBMC (63, 65, 66), T-cells (65), isotype control (63, } \\
65,66) \text {, competitive antibody binding, non-targeting } \\
\text { siRNA (65). }\end{array}$ & $\begin{array}{l}\mathrm{BNI} 3 \text { and A3.6B10.G1 (65); } \\
48815,14 \mathrm{D} 3 \text { and agonist 3D5 } \\
\text { (63) }\end{array}$ & $(63,65,66)$ \\
\hline & $\begin{array}{l}\text { Mouse bone marrow-derived dendritic } \\
\text { cells }\end{array}$ & $\begin{array}{l}\text { A. siRNA knockdown and western blot } \\
\text { B. siRNA knockdown with functional analysis }\end{array}$ & Non-targeting siRNA & Not provided & $(63,65,66)$ \\
\hline $\begin{array}{l}\text { MDSCs and } \\
\text { Macrophages }\end{array}$ & $\begin{array}{l}\text { Mouse MDSCs }\left(\mathrm{CD} 11 \mathrm{~b}^{+} \mathrm{Gr}-1^{+}\right) \text {and } \mathrm{M} 2 \\
\text { macrophages }\left(\mathrm{CD} 11 \mathrm{~b}^{+} \mathrm{F} 4 / 80^{+}\right)\end{array}$ & $\begin{array}{l}\text { A. Flow cytometry } \\
\text { B. Fluorescence microscopy }\end{array}$ & Isotype control & Not provided & (69) \\
\hline Granulocytes & G-CSF-treated human granulocytes & Flow cytometry & $\begin{array}{l}\text { CTLA-4-Ig-transfected J558L murine myeloma, } \\
\text { T-cells, isotype controls. }\end{array}$ & $\mathrm{BNI3}$ & $(47)$ \\
\hline $\begin{array}{l}{\mathrm{CD} 34^{+}}^{+} \\
\text {hematopoietic } \\
\text { stem cells }\end{array}$ & $\begin{array}{l}\text { GM-CSF-treated and untreated CD } 34^{+} \\
\text {stem cells }\end{array}$ & $\begin{array}{l}\text { A. Flow cytometry } \\
\text { B. Immunohistochemistry }\end{array}$ & $\begin{array}{l}\text { CTLA-4-Ig-transfected J558L murine myeloma, } \\
\text { T-cells, isotype control. }\end{array}$ & $\mathrm{BNI3}$ & $(47)$ \\
\hline \multirow[t]{2}{*}{$\begin{array}{l}\text { Immune cell } \\
\text { malignancies }\end{array}$} & $\begin{array}{l}\text { Non-Hodgkin's B-cell lymphoma } \\
\text { (follicular) }\end{array}$ & Immunohistochemistry & $\begin{array}{l}\text { CTLA-4-transfected cells and reactive lymph node } \\
\text { samples, Jurkat cells }\end{array}$ & $\mathrm{BNI3}$ & (70) \\
\hline & T-cell lymphoma (peripheral), T-CLL & Immunohistochemistry & $\begin{array}{l}\text { CTLA-4-transfected cells and reactive lymph node } \\
\text { samples, Jurkat cells }\end{array}$ & $\mathrm{BNI3}$ & (70) \\
\hline
\end{tabular}




\begin{tabular}{|c|c|c|c|c|c|}
\hline Cell type & & Experimental Evidence & Controls & Anti-CTLA-4 clone & Reference \\
\hline & $\begin{array}{l}\text { B-Chronic lymphocytic leukemia } \\
\text { (human and TCL1 transgenic mice) }\end{array}$ & $\begin{array}{ll}\text { A. } & \text { Microarray }(75-77) \\
\text { B. } & \text { Flow Cytometry }(47,75-77) \\
\text { C. } & \text { RT-PCR }(75,76) \\
\text { D. } & \text { siRNA knockdown }(76) \\
\text { E. } & \text { Western blot }(76)\end{array}$ & $\begin{array}{l}\text { Isotype control }(75,76), \text { CTLA-4-Ig-transfected } \\
\text { J558L murine myeloma (47), } \\
\text { T-cells (47), Jurkat cells (75), scrambled siRNA (76) }\end{array}$ & $\begin{array}{l}\text { BNI3 }(47,75), \text { UC10-4F10-11 } \\
\text { (75), 9d9 (75), }\end{array}$ & $(47,75-77)$ \\
\hline & AML, CML, B-ALL, T-CLL, LGL & A. Flow cytometry & $\begin{array}{l}\text { CTLA-4-Ig-transfected J558L murine myeloma, } \\
\text { T-cells, isotype controls. }\end{array}$ & $\mathrm{BNI3}$ & $(47)$ \\
\hline & $\begin{array}{l}\text { Raji and Daudi B- lymphoblastoid cell } \\
\text { lines }\end{array}$ & $\begin{array}{ll}\text { A. } & \text { Flow Cytometry }(47,71) \\
\text { B. } & \text { RT-PCR + nested PCR (47) }\end{array}$ & $\begin{array}{l}\text { T-cells }(47,71) \text {, CTLA-4-transfected J558L murine } \\
\text { myeloma (47) and isotype controls }(47,71) \text {. }\end{array}$ & BNI3 (47) & $(47,71)$ \\
\hline \multirow[t]{7}{*}{$\begin{array}{l}\text { Non-immune } \\
\text { cell } \\
\text { malignancies }\end{array}$} & $\begin{array}{l}\text { Human breast cancer cells and cell } \\
\text { lines (MDA-MB-231 MCF-7 SKBR3 } \\
\text { and T47D) }\end{array}$ & $\begin{array}{l}\text { A. Flow cytometry }(79) \\
\text { B. Functional analyses with antibody blockade } \\
\text { (79) } \\
\text { C. Immunohistochemistry }(78,112)\end{array}$ & $\begin{array}{l}\text { Isotype control (79), human tonsil section }(78,79, \\
112), \text { non-neoplastic breast epithelial tissue }(78), \\
\text { primary antibody solution pre-cleared with CTLA-4 } \\
\text { peptide (78) and sections stained with primary } \\
\text { antibody-free diluent (78) }\end{array}$ & $\begin{array}{l}\text { 14D3 (79), bs-1179R (78), F8 } \\
(112)\end{array}$ & $(78,79,112)$ \\
\hline & Melanoma & $\begin{array}{ll}\text { A. } & \text { Flow cytometry } \\
\text { B. Immunohistochemistry } \\
\text { C. } \\
\text { QRT-PCR } \\
\text { D. ELISA (soluble CTLA-4) }\end{array}$ & Isotype control & 14D3, Ipilimumab & (113) \\
\hline & Esophageal carcinoma & Immunohistochemistry & Not provided & EPR1476 & (81) \\
\hline & Nasopharyngeal carcinoma & Immunohistochemistry & Not provided & $\begin{array}{l}\text { Polyclonal antibody ( } 251548 \\
\text { Abbiotec), }\end{array}$ & (82) \\
\hline & Non-small cell lung cancer (NSCLC) & Immunohistochemistry & $\begin{array}{l}\text { Normal human placental tissue (86), brain tissue (86), } \\
\text { melanoma tissue (84) and isotype control }(84,86)\end{array}$ & 14D3 $(84,86)$ & $(84,86)$ \\
\hline & $\begin{array}{l}\text { Cholangiocarcinoma (extrahepatic bile } \\
\text { duct cancer) }\end{array}$ & Immunohistochemistry & Not provided & Polyclonal (Abcam ab151773) & (85) \\
\hline & Testicular germ cell cancer & $\begin{array}{l}\text { A. Immunohistochemistry } \\
\text { B. Analysis of TCGA datasets (mRNA) }\end{array}$ & Normal human placenta and tonsil tissue & Polyclonal (Thermofisher) & (83) \\
\hline \multirow[t]{3}{*}{$\begin{array}{l}\text { Non tumor/non- } \\
\text { hematopoietic }\end{array}$} & Mesenchymal stem cells & $\begin{array}{l}\text { A. RT-PCR } \\
\text { B. Western blot } \\
\text { C. Flow cytometry } \\
\text { D. Soluble CTLA-4 ELISA } \\
\text { E. Functional studies with CTLA-4 Ig blockade }\end{array}$ & Isotype control & $\mathrm{BNI3}$ & (103) \\
\hline & Placental fibroblast & $\begin{array}{l}\text { A. RT-PCR } \\
\text { B. Immunohistochemistry }\end{array}$ & Isotype control and activated T-cells & Not provided & (102) \\
\hline & $\begin{array}{l}\text { Keratinocytes and cervical epithelium } \\
\text { (HPVE7-induced) }\end{array}$ & $\begin{array}{ll}\text { A. } & \text { Microarray } \\
\text { B. } & \text { RT-PCR } \\
\text { C. Western blot } \\
\text { D. Flow cytometry } \\
\text { E. Immunohistochemistry }\end{array}$ & Isotype control & $\mathrm{BNI3}$ & (108) \\
\hline
\end{tabular}


immunosuppression, no consensus has been reached regarding the dominant mode of immune inhibition. These cells predominantly expressed the full-length CTLA-4 (flCTLA-4) and secreted soluble CTLA-4 (sCTLA-4), although other isoforms were also detected. MSC CTLA-4 was determined to inhibit TNF $\alpha$ production by PHA-activated PBMCs, a phenomenon that was boosted by hypoxic conditions. Accordingly, hypoxic culture conditions significantly upregulated the expression of flCTLA-4 and sCTLA-4 in MSCs (103).

Efforts to define the immunosuppressive landscape of the maternal-fetal landscape during pregnancy led to the discovery that fetal cells expressed CTLA-4 during gestation. Notably, cultured human placental fibroblasts and mesenchyme as well as placentas from all gestational time points expressed CTLA-4 (102).

In the same vein, viral infections, such as with Human Papilloma Virus (HPV) have been demonstrated to imprint an immunosuppressive phenotype upon the host organism (106, 107). HPV, in particular, has been shown to impair host NK and $\mathrm{T}$-cell antiviral responses through a variety of mechanisms including Treg recruitment, inhibition of DC maturation and suppression of NK cell cytotoxicity. In keeping with this theme, the HPV protein HPVE7, has been reported to induce CTLA-4 expression in human cervical epithelium and keratinocytes by promoting $\mathrm{H} 3 \mathrm{~K} 36 \mathrm{me} 2$ at the CTLA-4 promoter (108). While no functional characterization of CTLA- 4 in this context has been carried out, the authors hypothesize that it may contribute to the immunosuppressive phenotype and subsequent immune escape engendered by HPV.

\section{CONCLUSIONS}

The original characterizations of CTLA-4 function and biology were driven by the dramatic T-cell-intrinsic phenotype observed

\section{REFERENCES}

1. Brunet JF, Denizot F, Luciani MF, Roux-Dosseto M, Suzan M, Mattei MG, et al. A new member of the immunoglobulin superfamily-CTLA-4. Nature (1987) 328(6127):267-70. doi: 10.1038/328267a0

2. Azuma M, Ito D, Yagita H, Okumura K, Phillips JH, Lanier LL, et al. B70 antigen is a second ligand for CTLA-4 and CD28. Nature (1993) 366 (6450):76-9. doi: 10.1038/366076a0

3. Linsley PS, Brady W, Urnes M, Grosmaire LS, Damle NK, Ledbetter JA. CTLA-4 is a second receptor for the B cell activation antigen B7. J Exp Med (1991) 174(3):561-9. doi: 10.1084/jem.174.3.561

4. Linsley PS, Brady W, Grosmaire L, Aruffo A, Damle NK, Ledbetter JA. Binding of the B cell activation antigen B7 to CD28 costimulates $\mathrm{T}$ cell proliferation and interleukin 2 mRNA accumulation. J Exp Med (1991) 173 (3):721-30. doi: 10.1084/jem.173.3.721

5. Turka LA, Ledbetter JA, Lee $\mathrm{K}$, June $\mathrm{CH}$, Thompson CB. CD28 is an inducible $\mathrm{T}$ cell surface antigen that transduces a proliferative signal in CD3 + mature thymocytes. J Immunol (1990) 144(5):1646-53.

6. Guntermann C, Alexander DR. CTLA-4 suppresses proximal TCR signaling in resting human CD4(+) $\mathrm{T}$ cells by inhibiting ZAP-70 Tyr(319) phosphorylation: a potential role for tyrosine phosphatases. I Immunol (2002) 168(9):4420-9. doi: 10.4049/jimmunol.168.9.4420 in global knockout mice, animals that were born normal but died in the early postnatal period of massive and uncontrolled lymphoproliferation $(44,109)$. When follow-up studies that included concomitant global deletion of CD28 (110) as well as re-expression of CTLA-4 in null mice from the T-cell-specific Lck promotor (111) both rescued this dramatic but early phenotype, there remained little impetus to look for additional mechanisms of action outside the $\mathrm{T}$-cell compartment. In contrast to this early paradigm, studies over the last two decades have demonstrated both constitutive and inducible expression of CTLA-4 in a broad distribution of tissues and cell types (Table 1). This expansive pattern of expression and the circumstances under which induction may occur have necessitated a reevaluation of the role that CLTA-4 plays in global immune regulation. A variety of convincing studies (Table 1), particularly those in dendritic cells and tumors, now demonstrate that CTLA-4 plays nonredundant and critical roles in thymic development, $\mathrm{T}$-cell priming, peripheral tolerance, and a variety of other critical immunoregulatory functions. Further, it appears likely that additional roles for this central and highly versatile molecule will be uncovered as additional studies progress.

\section{AUTHOR CONTRIBUTIONS}

DO-S, VK, JV-P, JL, and WD all collaborated in the writing and editing of this manuscript. SW provided the original artwork. All authors contributed to the article and approved the submitted version.

\section{FUNDING}

This work was funded in part by NIH R01 AI127387 to WD.

7. Kong KF, Fu G, Zhang Y, Yokosuka T, Casas J, Canonigo-Balancio AJ, et al. Protein kinase C-eta controls CTLA-4-mediated regulatory T cell function. Nat Immunol (2014) 15(5):465-72. doi: 10.1038/ni.2866

8. Paterson AM, Lovitch SB, Sage PT, Juneja VR, Lee Y, Trombley JD, et al. Deletion of CTLA-4 on regulatory $\mathrm{T}$ cells during adulthood leads to resistance to autoimmunity. J Exp Med (2015) 212(10):1603-21. doi: 10.1084/jem.20141030

9. Pentcheva-Hoang T, Egen JG, Wojnoonski K, Allison JP. B7-1 and B7-2 selectively recruit CTLA-4 and CD28 to the immunological synapse. Immunity (2004) 21(3):401-13. doi: 10.1016/j.immuni.2004.06.017

10. Qureshi OS, Kaur S, Hou TZ, Jeffery LE, Poulter NS, Briggs Z, et al. Constitutive clathrin-mediated endocytosis of CTLA-4 persists during T cell activation. J Biol Chem (2012) 287(12):9429-40. doi: 10.1074/jbc.M111.304329

11. Hou TZ, Qureshi OS, Wang CJ, Baker J, Young SP, Walker LS, et al. A transendocytosis model of CTLA-4 function predicts its suppressive behavior on regulatory T cells. J Immunol (2015) 194(5):2148-59. doi: 10.4049/jimmunol.1401876

12. Krummel MF, Allison JP. CD28 and CTLA-4 have opposing effects on the response of T cells to stimulation. J Exp Med (1995) 182(2):459-65. doi: 10.1084/jem.182.2.459

13. Perez-Garcia A, Osca G, Bosch-Vizcaya A, Kelleher N, Santos NY, Rodriguez R, et al. Kinetics of the CTLA-4 isoforms expression after 
T-lymphocyte activation and role of the promoter polymorphisms on CTLA-4 gene transcription. Hum Immunol (2013) 74(9):1219-24. doi: 10.1016/j.humimm.2013.05.012

14. Perkins D, Wang Z, Donovan C, He H, Mark D, Guan G, et al. Regulation of CTLA-4 expression during T cell activation. J Immunol (1996) 156 (11):4154-9.

15. Lindsten T, Lee KP, Harris ES, Petryniak B, Craighead N, Reynolds PJ, et al. Characterization of CTLA-4 structure and expression on human T cells. J Immunol (1993) 151(7):3489-99.

16. Wing K, Onishi Y, Prieto-Martin P, Yamaguchi T, Miyara M, Fehervari Z, et al. CTLA-4 control over Foxp3+ regulatory T cell function. Science (2008) 322(5899):271-5. doi: 10.1126/science.1160062

17. Takahashi T, Tagami T, Yamazaki S, Uede T, Shimizu J, Sakaguchi N, et al. Immunologic self-tolerance maintained by $\mathrm{CD} 25(+) \mathrm{CD} 4(+)$ regulatory $\mathrm{T}$ cells constitutively expressing cytotoxic $\mathrm{T}$ lymphocyte-associated antigen 4 . J Exp Med (2000) 192(2):303-10. doi: 10.1084/jem.192.2.303

18. Read S, Greenwald R, Izcue A, Robinson N, Mandelbrot D, Francisco L, et al. Blockade of CTLA-4 on CD4+CD25+ regulatory T cells abrogates their function in vivo. J Immunol (2006) 177(7):4376-83. doi: 10.4049/ jimmunol.177.7.4376

19. Chuang E, Alegre ML, Duckett CS, Noel PJ, Vander Heiden MG, Thompson CB. Interaction of CTLA- 4 with the clathrin-associated protein AP50 results in ligand-independent endocytosis that limits cell surface expression. J Immunol (1997) 159(1):144-51.

20. Shiratori T, Miyatake S, Ohno H, Nakaseko C, Isono K, Bonifacino JS, et al. Tyrosine phosphorylation controls internalization of CTLA-4 by regulating its interaction with clathrin-associated adaptor complex AP-2. Immunity (1997) 6(5):583-9. doi: 10.1016/S1074-7613(00)80346-5

21. Banton MC, Inder KL, Valk E, Rudd CE, Schneider H. Rab8 binding to immune cell-specific adaptor LAX facilitates formation of trans-Golgi network-proximal CTLA-4 vesicles for surface expression. Mol Cell Biol (2014) 34(8):1486-99. doi: 10.1128/MCB.01331-13

22. Qureshi OS, Zheng Y, Nakamura K, Attridge K, Manzotti C, Schmidt EM, et al. Trans-endocytosis of CD80 and CD86: a molecular basis for the cellextrinsic function of CTLA-4. Science (2011) 332(6029):600-3. doi: 10.1126/ science. 1202947

23. Rudd CE, Taylor A, Schneider H. CD28 and CTLA-4 coreceptor expression and signal transduction. Immunol Rev (2009) 229(1):12-26. doi: 10.1111/ j.1600-065X.2009.00770.x

24. Bradshaw JD, Lu P, Leytze G, Rodgers J, Schieven GL, Bennett KL, et al. Interaction of the cytoplasmic tail of CTLA-4 (CD152) with a clathrinassociated protein is negatively regulated by tyrosine phosphorylation. Biochemistry (1997) 36(50):15975-82. doi: 10.1021/bi971762i

25. Iida T, Ohno H, Nakaseko C, Sakuma M, Takeda-Ezaki M, Arase H, et al. Regulation of cell surface expression of CTLA-4 by secretion of CTLA-4containing lysosomes upon activation of CD4+ T cells. J Immunol (2000) 165(9):5062-8. doi: 10.4049/jimmunol.165.9.5062

26. Lo B, Zhang K, Lu W, Zheng L, Zhang Q, Kanellopoulou C, et al. AUTOIMMUNE DISEASE. Patients with LRBA deficiency show CTLA4 loss and immune dysregulation responsive to abatacept therapy. Science (2015) 349(6246):436-40. doi: 10.1126/science.aaa1663

27. Alkhairy OK, Abolhassani H, Rezaei N, Fang M, Andersen KK, Chavoshzadeh Z, et al. Spectrum of Phenotypes Associated with Mutations in LRBA. J Clin Immunol (2016) 36(1):33-45. doi: 10.1007/ s10875-015-0224-7

28. Alroqi FJ, Charbonnier LM, Baris S, Kiykim A, Chou J, Platt CD, et al. Exaggerated follicular helper T-cell responses in patients with LRBA deficiency caused by failure of CTLA4-mediated regulation. J Allergy Clin Immunol (2018) 141(3):1050-9 e10. doi: 10.1016/j.jaci.2017.05.022

29. Charbonnier LM, Janssen E, Chou J, Ohsumi TK, Keles S, Hsu JT, et al. Regulatory T-cell deficiency and immune dysregulation, polyendocrinopathy, enteropathy, X-linked-like disorder caused by loss-of-function mutations in LRBA. J Allergy Clin Immunol (2015) 135(1):217-27. doi: 10.1016/j.jaci. 2014.10.019

30. Gamez-Diaz L, August D, Stepensky P, Revel-Vilk S, Seidel MG, Noriko M, et al. The extended phenotype of LPS-responsive beige-like anchor protein (LRBA) deficiency. J Allergy Clin Immunol (2016) 137(1):223-30. doi: 10.1016/j.jaci.2015.09.025
31. Lopez-Herrera G, Tampella G, Pan-Hammarstrom Q, Herholz P, TrujilloVargas CM, Phadwal K, et al. Deleterious mutations in LRBA are associated with a syndrome of immune deficiency and autoimmunity. Am J Hum Genet (2012) 90(6):986-1001. doi: 10.1016/j.ajhg.2012.04.015

32. Linsley PS, Greene JL, Brady W, Bajorath J, Ledbetter JA, Peach R. Human B7-1 (CD80) and B7-2 (CD86) bind with similar avidities but distinct kinetics to CD28 and CTLA-4 receptors. Immunity (1994) 1(9):793-801. doi: 10.1016/S1074-7613(94)80021-9

33. van der Merwe PA, Bodian DL, Daenke S, Linsley P, Davis SJ. CD80 (B7-1) binds both CD28 and CTLA-4 with a low affinity and very fast kinetics. J Exp Med (1997) 185(3):393-403. doi: 10.1084/jem.185.3.393

34. Yokosuka T, Kobayashi W, Takamatsu M, Sakata-Sogawa K, Zeng H, Hashimoto-Tane A, et al. Spatiotemporal basis of CTLA-4 costimulatory molecule-mediated negative regulation of T cell activation. Immunity (2010) 33(3):326-39. doi: 10.1016/j.immuni.2010.09.006

35. Tai X, Van Laethem F, Sharpe AH, Singer A. Induction of autoimmune disease in CTLA-4-/- mice depends on a specific CD28 motif that is required for in vivo costimulation. Proc Natl Acad Sci U S A (2007) 104(34):13756-61. doi: 10.1073/pnas.0706509104

36. Schneider H, Prasad KV, Shoelson SE, Rudd CE. CTLA-4 binding to the lipid kinase phosphatidylinositol 3-kinase in T cells. J Exp Med (1995) 181 (1):351-5. doi: $10.1084 /$ jem.181.1.351

37. Knieke K, Lingel H, Chamaon K, Brunner-Weinzierl MC. Migration of Th1 lymphocytes is regulated by CD152 (CTLA-4)-mediated signaling via PI3 kinase-dependent Akt activation. PloS One (2012) 7(3):e31391. doi: 10.1371/ journal.pone.0031391

38. Marengere LE, Waterhouse P, Duncan GS, Mittrucker HW, Feng GS, Mak TW. Regulation of T cell receptor signaling by tyrosine phosphatase SYP association with CTLA-4. Science (1996) 272(5265):1170-3. doi: 10.1126/ science. 272.5265 .1170

39. Lee KM, Chuang E, Griffin M, Khattri R, Hong DK, Zhang W, et al. Molecular basis of T cell inactivation by CTLA-4. Science (1998) 282 (5397):2263-6. doi: 10.1126/science.282.5397.2263

40. Teft WA, Chau TA, Madrenas J. Structure-Function analysis of the CTLA-4 interaction with PP2A. BMC Immunol (2009) 10:23. doi: 10.1186/14712172-10-23

41. Baroja ML, Vijayakrishnan L, Bettelli E, Darlington PJ, Chau TA, Ling V, et al. Inhibition of CTLA-4 function by the regulatory subunit of serine/ threonine phosphatase 2A. J Immunol (2002) 168(10):5070-8. doi: 10.4049/ jimmunol.168.10.5070

42. Pandiyan P, Gartner D, Soezeri O, Radbruch A, Schulze-Osthoff K, BrunnerWeinzierl MC. CD152 (CTLA-4) determines the unequal resistance of Th1 and Th2 cells against activation-induced cell death by a mechanism requiring PI3 kinase function. J Exp Med (2004) 199(6):831-42. doi: 10.1084/jem.20031058

43. Schneider H, Downey J, Smith A, Zinselmeyer BH, Rush C, Brewer JM, et al. Reversal of the TCR stop signal by CTLA-4. Science (2006) 313(5795):19725. doi: 10.1126/science.1131078

44. Waterhouse P, Penninger JM, Timms E, Wakeham A, Shahinian A, Lee KP, et al. Lymphoproliferative disorders with early lethality in mice deficient in Ctla-4. Science (1995) 270(5238):985-8. doi: 10.1126/science.270. 5238.985

45. Merlo A, Tenca C, Fais F, Battini L, Ciccone E, Grossi CE, et al. Inhibitory receptors CD85j, LAIR-1, and CD152 down-regulate immunoglobulin and cytokine production by human B lymphocytes. Clin Diagn Lab Immunol (2005) 12(6):705-12. doi: 10.1128/CDLI.12.6.705-712.2005

46. Pioli C, Gatta L, Ubaldi V, Doria G. Inhibition of IgG1 and IgE production by stimulation of the B cell CTLA-4 receptor. J Immunol (2000) 165 (10):5530-6. doi: 10.4049/jimmunol.165.10.5530

47. Pistillo MP, Tazzari PL, Palmisano GL, Pierri I, Bolognesi A, Ferlito F, et al. CTLA-4 is not restricted to the lymphoid cell lineage and can function as a target molecule for apoptosis induction of leukemic cells. Blood (2003) 101 (1):202-9. doi: 10.1182/blood-2002-06-1668

48. Quandt D, Hoff H, Rudolph M, Fillatreau S, Brunner-Weinzierl MC. A new role of CTLA-4 on B cells in thymus-dependent immune responses in vivo. J Immunol (2007) 179(11):7316-24. doi: 10.4049/jimmunol.179.11.7316

49. Sage PT, Paterson AM, Lovitch SB, Sharpe AH. The coinhibitory receptor CTLA-4 controls B cell responses by modulating $\mathrm{T}$ follicular helper, $\mathrm{T}$ 
follicular regulatory, and T regulatory cells. Immunity (2014) 41(6):1026-39. doi: 10.1016/j.immuni.2014.12.005

50. Kuiper HM, Brouwer M, Linsley PS, van Lier RA. Activated T cells can induce high levels of CTLA-4 expression on B cells. J Immunol (1995) 155 (4):1776-83.

51. Mabbott NA, Gray D. Identification of co-expressed gene signatures in mouse B1, marginal zone and B2 B-cell populations. Immunology (2014) 141 (1):79-95. doi: 10.1111/imm.12171

52. Gamez-Diaz L, Neumann J, Jager F, Proietti M, Felber F, Soulas-Sprauel P, et al. Immunological phenotype of the murine Lrba knockout. Immunol Cell Biol (2017) 95(9):789-802. doi: 10.1038/icb.2017.52

53. Stojanovic A, Fiegler N, Brunner-Weinzierl M, Cerwenka A. CTLA-4 is expressed by activated mouse NK cells and inhibits NK Cell IFN-gamma production in response to mature dendritic cells. J Immunol (2014) 192 (9):4184-91. doi: 10.4049/jimmunol.1302091

54. Lougaris V, Tabellini G, Baronio M, Patrizi O, Gazzurelli L, Mitsuiki N, et al. CTLA-4 regulates human Natural Killer cell effector functions. Clin Immunol (2018) 194:43-5. doi: 10.1016/j.clim.2018.06.010

55. Mirjacic Martinovic K, Babovic N, Dzodic R, Jurisic V, Matkovic S, Konjevic G. Favorable in vitro effects of combined IL-12 and IL-18 treatment on NK cell cytotoxicity and CD25 receptor expression in metastatic melanoma patients. $J$ Transl Med (2015) 13:120. doi: 10.1186/s12967-015-0479-z

56. Fehniger TA, Shah MH, Turner MJ, VanDeusen JB, Whitman SP, Cooper MA, et al. Differential cytokine and chemokine gene expression by human NK cells following activation with IL-18 or IL-15 in combination with IL-12: implications for the innate immune response. J Immunol (1999) 162 (8):4511-20.

57. Galea-Lauri J, Darling D, Gan SU, Krivochtchapov L, Kuiper M, Gaken J, et al. Expression of a variant of CD28 on a subpopulation of human NK cells: implications for B7-mediated stimulation of NK cells. J Immunol (1999) 163 (1):62-70.

58. Goodier MR, Londei M. CD28 is not directly involved in the response of human CD3- CD56+ natural killer cells to lipopolysaccharide: a role for T cells. Immunology (2004) 111(4):384-90. doi: 10.1111/j.0019-2805.2004.01834.x

59. Sallusto F, Lanzavecchia A. The instructive role of dendritic cells on T-cell responses. Arthritis Res (2002) 4 Suppl 3:S127-32. doi: 10.1186/ar567

60. Iezzi G, Karjalainen K, Lanzavecchia A. The duration of antigenic stimulation determines the fate of naive and effector T cells. Immunity (1998) 8(1):89-95. doi: 10.1016/S1074-7613(00)80461-6

61. Banchereau J, Steinman RM. Dendritic cells and the control of immunity. Nature (1998) 392(6673):245-52. doi: 10.1038/32588

62. Han Y, Chen Z, Yang Y, Jiang Z, Gu Y, Liu Y, et al. Human CD14+ CTLA-4+ regulatory dendritic cells suppress $\mathrm{T}$-cell response by cytotoxic $\mathrm{T}$ lymphocyte antigen-4-dependent IL-10 and indoleamine-2,3-dioxygenase production in hepatocellular carcinoma. Hepatology (2014) 59(2):567-79. doi: 10.1002/hep.26694

63. Laurent S, Carrega P, Saverino D, Piccioli P, Camoriano M, Morabito A, et al. CTLA-4 is expressed by human monocyte-derived dendritic cells and regulates their functions. Hum Immunol (2010) 71(10):934-41. doi: 10.1016/ j.humimm.2010.07.007

64. Wang XB, Giscombe R, Yan Z, Heiden T, Xu D, Lefvert AK. Expression of CTLA-4 by human monocytes. Scand J Immunol (2002) 55(1):53-60. doi: 10.1046/j.0300-9475.2001.01019.x

65. Halpert MM, Konduri V, Liang D, Chen Y, Wing JB, Paust S, et al. Dendritic Cell-Secreted Cytotoxic T-Lymphocyte-Associated Protein-4 Regulates the T-cell Response by Downmodulating Bystander Surface B7. Stem Cells Dev (2016) 25(10):774-87. doi: 10.1089/scd.2016.0009

66. Wang XB, Fan ZZ, Anton D, Vollenhoven AV, Ni ZH, Chen XF, et al. CTLA4 is expressed on mature dendritic cells derived from human monocytes and influences their maturation and antigen presentation. BMC Immunol (2011) 12:21. doi: 10.1186/1471-2172-12-21

67. Halpert MM, Konduri V, Liang D, Vazquez-Perez J, Hofferek CJ, Weldon $\mathrm{SA}$, et al. and II peptide homology regulates the cellular immune response. FASEB J (2020) 34(6):8082-101. doi: 10.1096/fj.201903002R

68. Dong MB, Rahman MJ, Tarbell KV. Flow cytometric gating for spleen monocyte and DC subsets: differences in autoimmune NOD mice and with acute inflammation. J Immunol Methods (2016) 432:4-12. doi: 10.1016/ j.jim.2015.08.015
69. Yu GT, Bu LL, Zhao YY, Mao L, Deng WW, Wu TF, et al. CTLA4 blockade reduces immature myeloid cells in head and neck squamous cell carcinoma. Oncoimmunology (2016) 5(6):e1151594. doi: 10.1080/2162402X. 2016.1151594

70. Xerri L, Devilard E, Hassoun J, Olive D, Birg F. In vivo expression of the CTLA4 inhibitory receptor in malignant and reactive cells from human lymphomas. J Pathol (1997) 183(2):182-7. doi: 10.1002/(SICI)1096-9896 (199710) 183:2<182::AID-PATH918>3.0.CO;2-I

71. Raiter A, Novogrodsky A, Hardy B. Activation of lymphocytes by BAT and anti CTLA-4: comparison of binding to T and B cells. Immunol Lett (1999) 69(2):247-51. doi: 10.1016/S0165-2478(99)00081-4

72. Greenwald RJ, Oosterwegel MA, van der Woude D, Kubal A, Mandelbrot DA, Boussiotis VA, et al. CTLA-4 regulates cell cycle progression during a primary immune response. Eur J Immunol (2002) 32(2):366-73. doi: 10.1002/1521-4141(200202)32:2<366::AID-IMMU366>3.0.CO;2-5

73. Brunner MC, Chambers CA, Chan FK, Hanke J, Winoto A, Allison JP. CTLA-4-Mediated inhibition of early events of $\mathrm{T}$ cell proliferation. J Immunol (1999) 162(10):5813-20. doi: 10.1002/1521-4141(200202) 32:2<366::AID-IMMU366>3.0.CO;2-5

74. Kosmaczewska A, Ciszak L, Suwalska K, Wolowiec D, Frydecka I. CTLA-4 overexpression in CD19+/CD5+ cells correlates with the level of cell cycle regulators and disease progression in B-CLL patients. Leukemia (2005) 19 (2):301-4. doi: 10.1038/sj.leu.2403588

75. Do P, Beckwith KA, Cheney C, Tran M, Beaver L, Griffin BG, et al. Leukemic B Cell CTLA-4 Suppresses Costimulation of T Cells. J Immunol (2019) 202 (9):2806-16. doi: 10.4049/jimmunol.1801359

76. Mittal AK, Chaturvedi NK, Rohlfsen RA, Gupta P, Joshi AD, Hegde GV, et al. Role of CTLA4 in the proliferation and survival of chronic lymphocytic leukemia. PloS One (2013) 8(8):e70352. doi: 10.1371/journal.pone.0070352

77. Joshi AD, Hegde GV, Dickinson JD, Mittal AK, Lynch JC, Eudy JD, et al. ATM, CTLA4, MNDA, and HEM1 in high versus low CD38 expressing Bcell chronic lymphocytic leukemia. Clin Cancer Res (2007) 13(18 Pt 1):5295304. doi: 10.1158/1078-0432.CCR-07-0283

78. Yu H, Yang J, Jiao S, Li Y, Zhang W, Wang J. Cytotoxic T lymphocyte antigen 4 expression in human breast cancer: implications for prognosis. Cancer Immunol Immunother (2015) 64(7):853-60. doi: 10.1007/s00262015-1696-2

79. Chen X, Shao Q, Hao S, Zhao Z, Wang Y, Guo X, et al. CTLA-4 positive breast cancer cells suppress dendritic cells maturation and function. Oncotarget (2017) 8(8):13703-15. doi: 10.18632/oncotarget.14626

80. Santoni G, Amantini C, Morelli MB, Tomassoni D, Santoni M, Marinelli O, et al. High CTLA-4 expression correlates with poor prognosis in thymoma patients. Oncotarget (2018) 9(24):16665-77. doi: 10.18632/oncotarget.24645

81. Zhang XF, Pan K, Weng DS, Chen CL, Wang QJ, Zhao JJ, et al. Cytotoxic T lymphocyte antigen-4 expression in esophageal carcinoma: implications for prognosis. Oncotarget (2016) 7(18):26670-9. doi: 10.18632/oncotarget.8476

82. Huang PY, Guo SS, Zhang Y, Lu JB, Chen QY, Tang LQ, et al. Tumor CTLA4 overexpression predicts poor survival in patients with nasopharyngeal carcinoma. Oncotarget (2016) 7(11):13060-8. doi: 10.18632/oncotarget.7421

83. Lobo J, Rodrigues A, Guimaraes R, Cantante M, Lopes P, Mauricio J, et al. Detailed Characterization of Immune Cell Infiltrate and Expression of Immune Checkpoint Molecules PD-L1/CTLA-4 and MMR Proteins in Testicular Germ Cell Tumors Disclose Novel Disease Biomarkers. Cancers (Basel) (2019) 11(10):1535. doi: 10.3390/cancers11101535

84. Salvi S, Fontana V, Boccardo S, Merlo DF, Margallo E, Laurent S, et al. Evaluation of CTLA-4 expression and relevance as a novel prognostic factor in patients with non-small cell lung cancer. Cancer Immunol Immunother (2012) 61(9):1463-72. doi: 10.1007/s00262-012-1211-y

85. Lim YJ, Koh J, Kim K, Chie EK, Kim S, Lee KB, et al. Clinical Implications of Cytotoxic T Lymphocyte Antigen-4 Expression on Tumor Cells and TumorInfiltrating Lymphocytes in Extrahepatic Bile Duct Cancer Patients Undergoing Surgery Plus Adjuvant Chemoradiotherapy. Target Oncol (2017) 12(2):211-8. doi: 10.1007/s11523-016-0474-1

86. Paulsen EE, Kilvaer TK, Rakaee M, Richardsen E, Hald SM, Andersen S, et al. CTLA-4 expression in the non-small cell lung cancer patient tumor microenvironment: diverging prognostic impact in primary tumors and lymph node metastases. Cancer Immunol Immunother (2017) 66(11):144961. doi: $10.1007 / \mathrm{s} 00262-017-2039-2$ 
87. Mo X, Zhang H, Preston S, Martin K, Zhou B, Vadalia N, et al. Interferongamma Signaling in Melanocytes and Melanoma Cells Regulates Expression of CTLA-4. Cancer Res (2018) 78(2):436-50. doi: 10.1158/0008-5472.CAN17-1615

88. Pistillo MP, Carosio R, Grillo F, Fontana V, Mastracci L, Morabito A, et al. Phenotypic characterization of tumor CTLA-4 expression in melanoma tissues and its possible role in clinical response to Ipilimumab. Clin Immunol (2020) 215:108428. doi: 10.1016/j.clim.2020.108428

89. Zhang B, Dang J, Ba D, Wang C, Han J, Zheng F. Potential function of CTLA-4 in the tumourigenic capacity of melanoma stem cells. Oncol Lett (2018) 16(5):6163-70. doi: 10.3892/ol.2018.9354

90. Liu GY, Liu Y, Lu Y, Qin YR, Di GH, Lei YH, et al. Short-term memory of danger signals or environmental stimuli in mesenchymal stem cells: implications for therapeutic potential. Cell Mol Immunol (2016) 13 (3):369-78. doi: 10.1038/cmi.2015.11

91. Liotta F, Angeli R, Cosmi L, Fili L, Manuelli C, Frosali F, et al. Toll-like receptors 3 and 4 are expressed by human bone marrow-derived mesenchymal stem cells and can inhibit their T-cell modulatory activity by impairing Notch signaling. Stem Cells (2008) 26(1):279-89. doi: 10.1634/stemcells.2007-0454

92. Bautista-Hernandez LA, Gomez-Olivares JL, Buentello-Volante B, Bautistade Lucio VM. Fibroblasts: The Unknown Sentinels Eliciting Immune Responses Against Microorganisms. Eur J Microbiol Immunol (Bp) (2017) 7(3):151-7. doi: 10.1556/1886.2017.00009

93. Zhang Y, Cao HJ, Graf B, Meekins H, Smith TJ, Phipps RP. CD40 engagement up-regulates cyclooxygenase-2 expression and prostaglandin E2 production in human lung fibroblasts. J Immunol (1998) 160(3):1053-7.

94. Zhang M, Tang H, Guo Z, An H, Zhu X, Song W, et al. Splenic stroma drives mature dendritic cells to differentiate into regulatory dendritic cells. Nat Immunol (2004) 5(11):1124-33. doi: 10.1038/ni1130

95. Huber LC, Distler O, Tarner I, Gay RE, Gay S, Pap T. Synovial fibroblasts: key players in rheumatoid arthritis. Rheumatol (Oxford) (2006) 45(6):66975. doi: 10.1093/rheumatology/kel065

96. Nistico L, Buzzetti R, Pritchard LE, Van der Auwera B, Giovannini C, Bosi E, et al. The CTLA-4 gene region of chromosome $2 \mathrm{q} 33$ is linked to, and associated with, type 1 diabetes. Belgian Diabetes Registry. Hum Mol Genet (1996) 5(7):1075-80. doi: 10.1093/hmg/5.7.1075

97. Borysewicz-Sanczyk H, Sawicka B, Wawrusiewicz-Kurylonek N, GlowinskaOlszewska B, Kadlubiska A, Goscik J, et al. Genetic Association Study of IL2RA, IFIH1, and CTLA-4 Polymorphisms With Autoimmune Thyroid Diseases and Type 1 Diabetes. Front Pediatr (2020) 8:481. doi: 10.3389/ fped.2020.00481

98. Fathima N, Narne P, Ishaq M. Association and gene-gene interaction analyses for polymorphic variants in CTLA-4 and FOXP3 genes: role in susceptibility to autoimmune thyroid disease. Endocrine (2019) 64(3):591604. doi: 10.1007/s12020-019-01859-3

99. Liu J, Zhang HX. CTLA-4 polymorphisms and systemic lupus erythematosus: a comprehensive meta-analysis. Genet Test Mol Biomarkers (2013) 17(3):226-31. doi: 10.1089/gtmb.2012.0302

100. Jury EC, Flores-Borja F, Kalsi HS, Lazarus M, Isenberg DA, Mauri C, et al. Abnormal CTLA-4 function in T cells from patients with systemic lupus erythematosus. Eur J Immunol (2010) 40(2):569-78. doi: 10.1002/ eji.200939781

101. Hunt KA, McGovern DP, Kumar PJ, Ghosh S, Travis SP, Walters JR, et al. A common CTLA4 haplotype associated with coeliac disease. Eur J Hum Genet (2005) 13(4):440-4. doi: 10.1038/sj.ejhg.5201357
102. Kaufman KA, Bowen JA, Tsai AF, Bluestone JA, Hunt JS, Ober C. The CTLA-4 gene is expressed in placental fibroblasts. Mol Hum Reprod (1999) 5 (1):84-7. doi: 10.1093/molehr/5.1.84

103. Gaber T, Schonbeck K, Hoff H, Tran CL, Strehl C, Lang A, et al. CTLA-4 Mediates Inhibitory Function of Mesenchymal Stem/Stromal Cells. Int J Mol Sci (2018) 19(8):2312. doi: 10.3390/ijms19082312

104. Nagaraju K, Raben N, Villalba ML, Danning C, Loeffler LA, Lee E, et al. Costimulatory markers in muscle of patients with idiopathic inflammatory myopathies and in cultured muscle cells. Clin Immunol (1999) 92(2):161-9. doi: 10.1006/clim.1999.4743

105. Ghannam S, Bouffi C, Djouad F, Jorgensen C, Noel D. Immunosuppression by mesenchymal stem cells: mechanisms and clinical applications. Stem Cell Res Ther (2010) 1(1):2. doi: 10.1186/scrt2

106. Zhou C, Tuong ZK, Frazer IH. Papillomavirus Immune Evasion Strategies Target the Infected Cell and the Local Immune System. Front Oncol (2019) 9:682. doi: 10.3389/fonc.2019.00682

107. Rouse BT, Horohov DW. Immunosuppression in viral infections. Rev Infect Dis (1986) 8(6):850-73. doi: 10.1093/clinids/8.6.850

108. Zhou Q, Chen L, Song Y, Ma L, Xiao P, Chen L, et al. Induction of coinhibitory molecule CTLA-4 by human papillomavirus E7 protein through downregulation of histone methyltransferase JHDM1B expression. Virology (2019) 538:111-8. doi: 10.1016/j.virol.2019.10.001

109. Tivol EA, Borriello F, Schweitzer AN, Lynch WP, Bluestone JA, Sharpe AH. Loss of CTLA-4 leads to massive lymphoproliferation and fatal multiorgan tissue destruction, revealing a critical negative regulatory role of CTLA-4. Immunity (1995) 3(5):541-7. doi: 10.1016/1074-7613(95)90125-6

110. Mandelbrot DA, Oosterwegel MA, Shimizu K, Yamada A, Freeman GJ, Mitchell RN, et al. B7-dependent T-cell costimulation in mice lacking CD28 and CTLA4. J Clin Invest (2001) 107(7):881-7. doi: 10.1172/JCI11710

111. Masteller EL, Chuang E, Mullen AC, Reiner SL, Thompson CB. Structural analysis of CTLA-4 function in vivo. J Immunol (2000) 164(10):5319-27. doi: 10.4049/jimmunol.164.10.5319

112. Kassardjian A, Shintaku PI, Moatamed NA. Expression of immune checkpoint regulators, cytotoxic T lymphocyte antigen 4 (CTLA-4) and programmed death-ligand 1 (PD-L1), in female breast carcinomas. PloS One (2018) 13(4):e0195958. doi: 10.1371/journal.pone.0195958

113. Laurent S, Queirolo P, Boero S, Salvi S, Piccioli P, Boccardo S, et al. The engagement of CTLA-4 on primary melanoma cell lines induces antibodydependent cellular cytotoxicity and TNF-alpha production. J Transl Med (2013) 11:108. doi: 10.1186/1479-5876-11-108

Conflict of Interest: Institutional policy requires VK and WD to declare their ownership stakes in Diakonos Research, Ltd.

The remaining authors declare that the research was conducted in the absence of any commercial or financial relationships that could be construed as a potential conflict of interest.

Copyright (C) 2020 Oyewole-Said, Konduri, Vazquez-Perez, Weldon, Levitt and Decker. This is an open-access article distributed under the terms of the Creative Commons Attribution License (CC BY). The use, distribution or reproduction in other forums is permitted, provided the original author(s) and the copyright owner(s) are credited and that the original publication in this journal is cited, in accordance with accepted academic practice. No use, distribution or reproduction is permitted which does not comply with these terms. 